Annals of Warsaw University of Life Sciences - SGGW

Land Reclamation No 39, 2008: 95-101

(Ann. Warsaw Univ. of Life Sci. - SGGW, Land Reclam. 39, 2008)

\title{
Ploughed-on terraces in loess landscape of strongly developed high plains
}

\author{
MAGDALENA PATRO, TADEUSZ WEGGOREK, TOMASZ ZUBALA \\ Department of Land Reclamation and Agricultural Structures, University of Life Sciences in Lublin
}

\begin{abstract}
Ploughed-on terraces in loess landscape of strongly developed high plains. The ploughed-on terraces were one of the techniques for agricultural use of steep slopes in loess landscapes of developed high plains, the example of which is described fragment of the valley in Bartłomiejowice near Nałęczów. Giving up the agricultural use makes disappearance of those anthropogenic-erosion relief forms in the landscape structure. The authors postulate to protect - by restoring the meadow-pasture use - the characteristic enclaves of loess landscapes with ploughed-on terraces.
\end{abstract}

Key words: ploughed-on terraces, loess landscape, soil erosion.

\section{INTRODUCTION}

Within the classification of Polish landscapes referring to loess uplands, Kondracki (1999) distinguishes the landscape type of "strongly developed high plains". They can be found mainly in central part of Lubelska Upland and south-western fragment of Nałęczów Plateau (Kondracki 1999) - in Kazimierski Landscape Park. These landscapes are characterized by dense network of dry valleys and ravines as an effect of geological processes and agricultural activity already begun in New Stone Age (Nogaj-Chachaj 1991).
The agricultural activities, besides erosion intensification and increasing the ravine network (Józefaciuk et al. 2002), remained apparent traces in loess slopes structure - bench and ridge terraces (Baryła and Pierzgalski 2005) forming by using earth-moving machines and ploughed-on terraces (cultivated terraces). The ploughed-on terraces are the most obvious indicator of cultivation erosion (Bac 1950; Harasimiuk et al. 1999; Twardy 1996) and at the same time being the cultivation system that reduces the water erosion (Bennett 1955; Mazur et al. 1985; Pałys 1985; Ziemnicki 1955, 1959; Ziemnicki et al. 1975). The ploughed-on terraces are formed as a result of ploughing in direction transverse to a slope under conditions of "historical" field pattern across the slope or they are the effects of anti-erosion farm management (band-type filed system). The banded field pattern formed due to ploughing with the furrow turn down the slope was introduced in large farms in 50-60's of the 20th century. In most cases, they were closed down due to difficulties associated with mechanization of field works. Although the ploughed-on terraces formed in a forced way by property boundaries remained as a relief 
form, but in general, they are not used as arable lands.

The present study was aimed at assessing the influence of long-term cultivation across the slope on morphology of loess valley slopes (western part of Nałęczów Plateau) and tendencies in changes of land use in an aspect of values of strongly developed high plains within loess landscape.

\section{MATERIAL AND METHODS}

The studies were carried out in the estuary of dry valley (Fig. 1) cutting slope of the Bystra river valley, on fields belonging to Bartłomiejowice village, about $7 \mathrm{~km}$ west from Nałęczów. The total area of the dry valley catchment is 105 ha, and average inclination $4.9 \%$ (Zubala et al. 2006).
Levelling section A-B perpendicular to the valley and ploughed-on terraces was made in 2006 (Fig. 1). The land use on terraces was recorded and compared with records on land registration maps from 1991. The condition of terraces scarps protection was assessed and their heights out of levelling section were measured.

\section{RESULTS}

The levelling section is presented in Figure 2. There is a ground road of $4.5 \mathrm{~m}$ width deepened to about $0.5 \mathrm{~m}$ at the valley bottom. It drains the water runoffs from the whole catchment.

The north-western slope (NW) is $70 \mathrm{~m}$ long and average inclination almost $21 \%$ (Phot. 1). It sharply changes into relatively flat part of a ridge cut by a deep

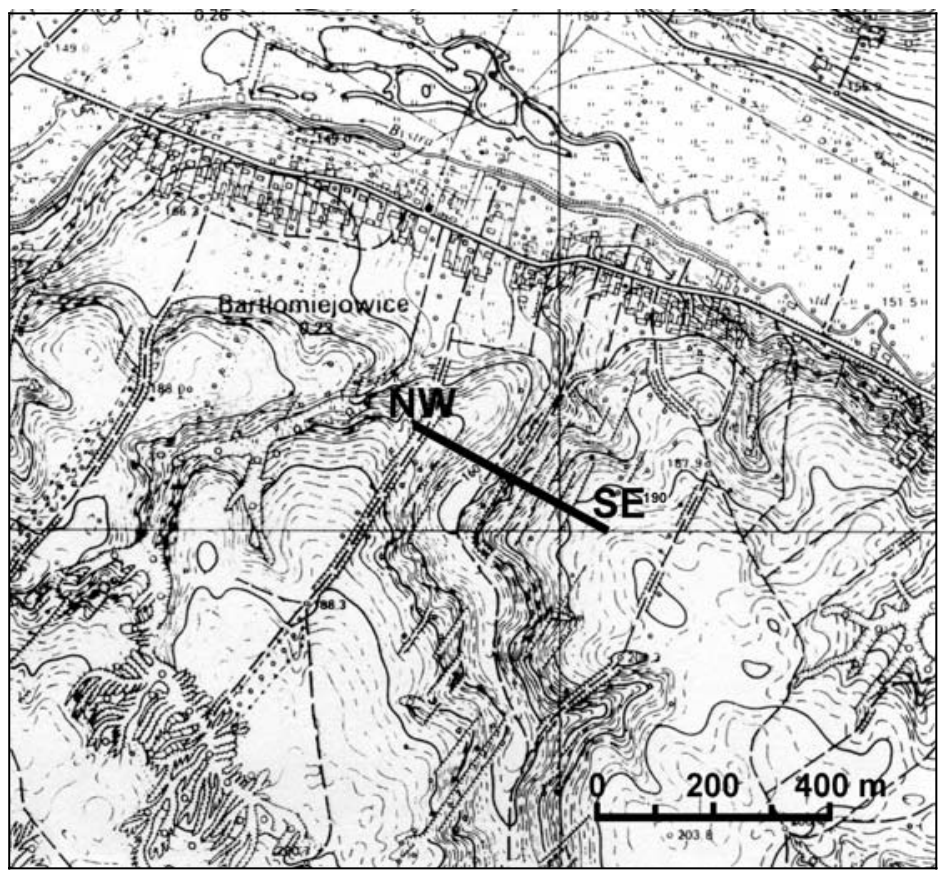

FIGURE 1. Research site: NW-SE - the cross section presented at Figure 2 


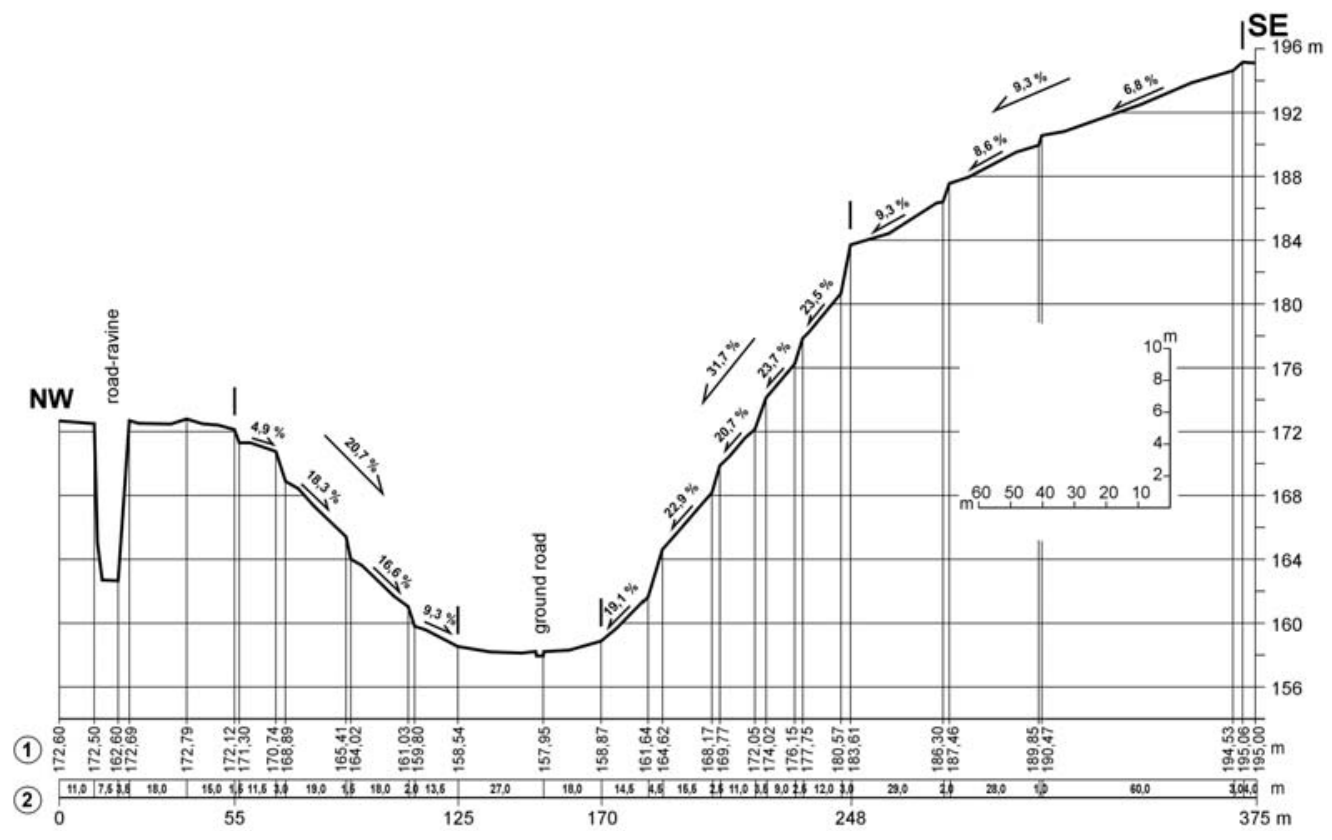

FIGURE 2. The cross section of slope valley (according to localization given at Figure 1): 1 - height above sea-level; 2 - distances

(10 m) road ravine (Fig. 1 and 2). The south-eastern slope (SE) is of almost $32 \%$ mean inclination at $78 \mathrm{~m}$ distance (from the valley bottom) and changes into relatively flat slope of slightly over $9 \%$ inclination. Both slopes, at whole distance, are terraced due to transverse cultivation forced by property boundaries. Particular terraces, at whole distance (200-250 m), have constant width. Their boundaries (scarps) are perpendicular to general slope direction. However, the slopes are cut with small valleys, which makes that such parameters as longitudinal and transverse inclinations of benches as well as scarps heights and inclinations change greatly within particular terraces (Phot. 1 and 2). In places where terraces are loca -lized across to valleys cutting the slopes (Fig. 1, Phot. 1 and 2), the longitudinal inclinations of terraces platforms reach $22 \%$ on NW and $27 \%$ on SE slope.

There are 4 terraces on NW slope, including the lowest one (along the valley bottom edge) without bottom scarp. Bench of this terrace was formed due to ploughing along the field's upper boundary. Widths of benches are 11.5$-19.0 \mathrm{~m}$, and their mean cross-falls from about $5 \%$ to over $18 \%$. All terraces platforms, within about 3-meter wide band, along the scarps bottoms have lower inclinations resulting from the cultivation erosion. Along the levelling section, scarps are of about $0.8-1.8 \mathrm{~m}$ height and 1:2-1:1 inclination.

There are 5 terraces on SE slope at its bottom steep fragment (terrace adjacent to the valley bottom is formed analogously as on NW slope). The benches are 


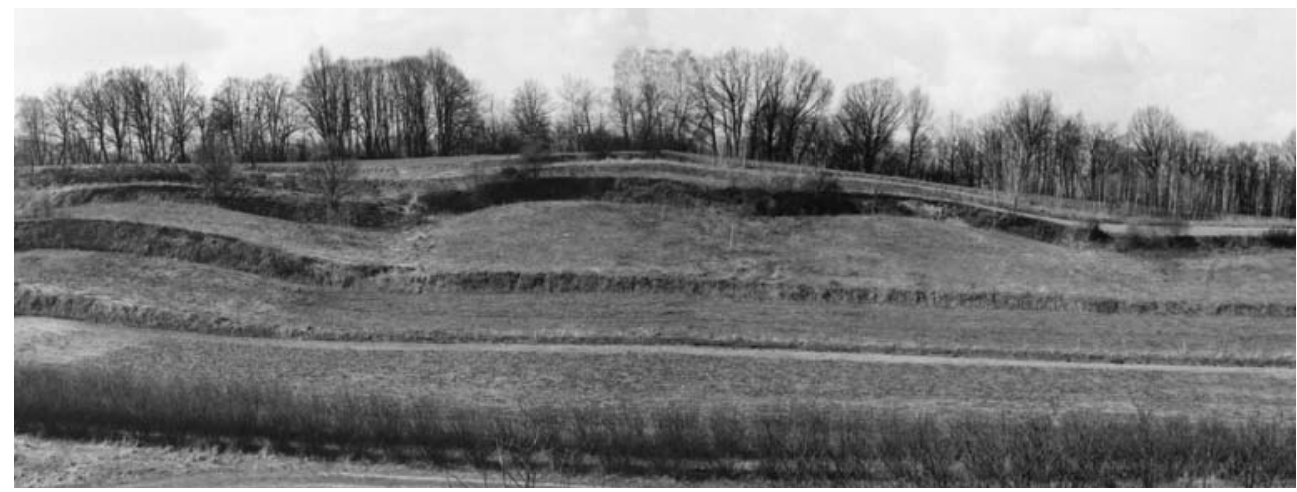

PHOT. 1. The north-western slope (NW), in the background - plantings along road ravine (spring 2006)

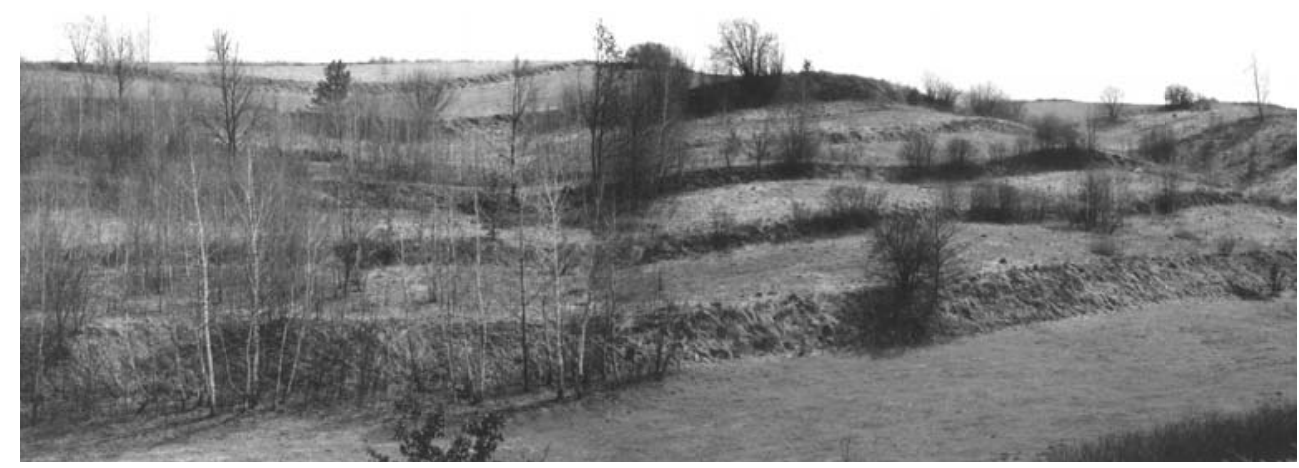

PHOT. 2. The lower (steep) part of south-eastern slope (SE) - spring 2006

9.0-15.5 $\mathrm{m}$ wide, and from about $19 \%$ to almost $24 \%$ inclined. Due to a large cross-falls of benches, there are not bands with apparently lower inclination along scarps bottoms. Their heights within that slope fragment are from 1.6 to about $3 \mathrm{~m}$ at 1:1.5-1:1 inclination. Upper part of the slope is divided into 3 wide $(28-60 \mathrm{~m})$ terraces with relatively low scarps $(0.5-1 \mathrm{~m})$. The mean benches inclinations are $7-9 \%$, but as the result of ploughing and water runoff there are erosion landforms below as well as accumulation above terraces scarps (Fig. 2).

Within the levelling section, the scarps heights, in general, did not exceed $3 \mathrm{~m}$, and their inclinations were lower than 1:1. However, in some places, they reach $3.5 \mathrm{~m}$ height (SE slope). In general, scarps inclination is not more than $1: 1$, but on NW slope (insolated exposure), there are almost vertical scarps up to $4.5 \mathrm{~m}$ height on short fragments. Most scarps are very well fixed by green plants, mainly grasses. Blackberries climbing even the vertical scarps cover a significant percentage of NW slope. On SE slope, an intensive shrubs and trees growing can be observed (Phot. 1 and 2).

For several past years, great land use changes have been occurred in whole catchmentofdryvalley(Zubalaetal.2006), 
especially on its slopes including ploughed-on terraces. According to land registration maps from 1991, terraced slopes and valley bottom were under plough tillage. In 2007, all terraces on a steep fragment of SE slope $(31.7 \%$ of mean inclination - Fig. 2) were sodded on the whole length (Phot. 2). Also higher terrace (with $9.3 \%$ inclination) was sodded. The plough tillage was performed only in the upper parts of the slope on $6.8 \%$ and $8.6 \%$ inclination terraces (Fig. 2). On NW slope in spring 2006, the $18.3 \%$ inclined terrace was about 3-year-old fallow land, and on lower $16.6 \%$ inclined one the field was not cultivated (Fig. 2, Phot. 1). Plantations of berry fruits in the sod were set on those terraces in 2006-2007. Highest localized terrace $(4.9 \%$ inclination) is partially grown with pines. The lowest situated terrace $(9.3 \%$ inclination) and valley bottom (NW side of the road) is used as plough land, except a narrow band along the road grown with fruit shrubs (Phot. 1). At the other side of the road (SE), the valley bottom is sodded. Trees grow onto the terraces benches, especially at the scarp's bottoms on SE slope (wetter sites). In general, they are small groups of several-year-old trees (mainly birch), including some covering several acre areas.

Described the valley fragment, that is strongly sculptured by natural processes and agricultural activities, is a valuable landscape enclave from ecological, esthetical and historical points of view. Ploughed-on terraces on such steep valley slopes and at similar arrangement as in Bartłomiejowice are rare, even in loess landscape of strongly developed high plains. In many cases, attractive erosion forms (including those being a result of cultivation erosion) get afforested due to a man or succession process (Orlik and Węgorek 2000; Pałys and Węgorek 1997). Under conditions of described valley fragment, growing of existing and appearing of new tree groups on terrace platforms is reduced by extensive grazing, and mainly by annual single cutting. Giving up these operations would cause the driving out the naturally valuable extensive green lands, mainly on sculptured areas (Fatyga 2003; Lipski and Kostuch 2005; Witkowski 2001) and further, "hiding in the forest" the monuments of agricultural culture - ploughed-on terraces.

\section{CONCLUSIONS}

- The ploughed-on terraces being an apparent cultural element in landscapes of developed loess high plains are one of the historical tillage systems on steep slopes.

- The tree press due to succession or artificial afforesting makes the disappearance of those anthropogenic-erosion forms in the landscape structure.

- In order to store ploughed-on terraces as the monuments of agricultural culture, their maintenance as durable extensive meadow-pasture use with annual scarps protection against excessive tree and shrubs growing seems to be the most appropriate solution.

- For landscape and cultural reasons, objects like described fragment of the valley should be under conservator's protection.

\section{REFERENCES}

BAC S. 1950: Wpływ pracy pługa na przemieszczanie gleb [The result of plough work on soil translocation]. Rocz. Nauk Rol. 54, 61-80. 
BARYŁA A., PIERZGALSKI E. 2005: Analiza metod obliczania rozstawy tarasów grzbietowych [Analysis of methods for calculation of ridge terraces spacing]. Acta Agrophysica 5 (2), 263-270 [Engl. summ.].

BENNETT H.H. 1955: Elements of soil conservation. McGraw-Hill Book Com., New York - Toronto - London.

FATYGA J. 2003: The conditions of spatial restructuring of grassland management in the Sudetes. Journal of Water and Land Development 7, 101-115.

HARASIMIUK M., RODZIK J., ZGŁOBICKI W. 1999: Influence of tillage erosion on refief of loess areas in the Lublin Upland and Roztocze (SE Poland). 2nd International Symposium on Tillage Erosion and Tillage Translocation, Leuven, Belgium. Book of abstracts.

JÓZEFACIUK CZ., JÓZEFACIUK A., NOWOCIEŃ E., WAWER R., PODOLSKI B. 2002: Struktura przestrzenna i ilościowa zagrożenia użytków rolnych erozją wodną powierzchniową w zlewni potoku Grodarz na Płaskowyżu Nałęczowskim [Spatial and quantitative structure of arable lands threats due to surface water erosion within the catchment of Grodarz stream on Nałęczów Plateau]. Fragm. Agronom. 1 (73), 95-111.

KONDRACKI J. 1999: Krajobrazy naturalne - mapa [Natural landscapes - map]. In: Starkel L. [Ed.]. Geografia Polski. Środowisko przyrodnicze [Geography of Poland. Natural Environment], PWN.

LIPSKI CZ., KOSTUCH R. 2005: Kształtowanie krajobrazów terenów erodowanych [Landscapes forming on eroded soils]. Acta Agrophysica 5 (2), 245-252 [Engl. summ.].

MAZUR Z., PAŁYS S., WĘGOREK T. 1985: Przeciwerozyjna funkcja pól wstegowych i zadrzewień pasowych na rędzinach [Antierosive function of ribbon-like fields and belt protective afforestation on rendzinas]. Zesz. Probl. Post. Nauk Roln. 311, 159-167 [Engl. summ.].

NOGAJ-CHACHAJ J. 1991: The stone-packed graves of the Funnel Beaker culture in Karmanowice, site 35. Antiquity 65, 628-639.

ORLIK T., WĘGOREK T. 2000: Renaturyzacja gruntów porolnych na terenie Krzczonowskiego Parku Krajobrazowego [Restoration of the post-agricultural lands in the area of Krzczonowski Landscape Park]. In: Renaturyzacja obiektów przyrodniczych - aspekty ekologiczne i gospo- darcze [Restoration of natural objects - ecological and economical aspects]. Wyd. UMCS, 273-277 [Engl. summ.].

PAŁYS S. 1985: Zmiany w rzeźbie i pokrywie glebowej w terenie lessowym objętym zabiegami przeciwerozyjnymi [Changes in the area relief and soil cover in the region of loess soils comprised with antierosion measures]. Zesz. Probl. Post. Nauk Roln. 292, 39-63 [Engl. summ.].

PAŁYS S., WEGGOREK T. 1997: Wąwozy lessowe jako osobliwość okolic Sandomierza [Loess ravines as curiosity of Sandomierz surroundings]. In: Osobliwości przyrody Ziemi Sandomierskiej [Curiosity of nature of Sandomierska Land]. Wyd. TNS, Sandomierz, 21-29.

TWARDY J. 1996: Wyniki badań tempa denudacji agrotechnicznej stoków użytkowanych rolniczo na przykładzie strefy krawędziowej Wyżyny Łódzkiej [The value of present-day agricultural denudation on cultivated slopes in the edge zone of the Łódź Plateau]. In: Ochrona agroekosystemów zagrożonych erozja [The conservation of agroecosystems threatened by erosion], IUNG, 2, 321-330 [Engl. summ.].

WITKOWSKI Z.J. 2001: Ochrona przyrody a program zwiększenia lesistości Polski [Nature conservation and the Polish Programme of Afforestation]. Sylwan CXLV, 3, 15-26 [Engl. summ.].

ZIEMNICKI S. 1955: Ochrona gleb przed erozją wodną stosowana przez rolników w niektórych rejonach Polski [Soil defense measures in the control of water erosion applied by farmers in some regions of Poland]. Ann. UMCS X, 2, B, 109-178 [Engl. Summ.].

ZIEMNICKI S. 1959: Znaczenie skarpy w terenie erozyjnym [The significance of scarps in area subject to erosion]. Rocz. Nauk Roln. 73-F-4, 715-746 [Engl. summ.].

ZIEMNICKI S., ORZECHOWSKI J., ORLIK T., RZEDZICKI Z. 1975: Przemieszczanie gleby przez pług i jakość orki na zboczu [Displacement of the soil by the plough, and the quality of ploughing on the slope]. Zesz. Probl. Post. Nauk Roln. 170, 115-128 [Engl. summ.].

ZUBALA T., WEQGOREK T., PATRO M. 2006: Zmiany użytkowania gleb silnie urzeźbionej zlewni w aspekcie ochrony krajobrazu [The soil use changes in high relief catchment in aspect of the landscape conservation]. Rocz. Glebozn. LVII, 3/4, 144-150 [Engl. summ.]. 
Streszczenie: Tarasy naorywane $w$ krajobrazie lessowym wysoczyzn silnie rozwiniętych. W krajobrazach lessowych wysoczyzn rozwiniętych jedną $z$ technik rolniczego użytkowania stromych stoków były tarasy naorywane - wyraźnym przykładem jest opisywany odcinek doliny we wsi Bartłomiejowice koło Nałęczowa. Zaprzestanie użytkowania rolniczego powoduje zanik w fizjonomii krajobrazu tych antropogeniczno-erozyjnych form rzeźby. Autorzy postulują objęcie ochroną konserwatorską (polegającą na utrzymaniu użytkowania łąkowo-pastwiskowego) charakterystycz- nych enklaw krajobrazów lessowych z tarasami naorywanymi.

MS. received April 2008

Authors' address:

Katedra Melioracji i Budownictwa Rolniczego

Uniwersytet Przyrodniczy w Lublinie ul. S. Leszczyńskiego 7, 20-069 Lublin

Poland

e-mail: magdalenapatro@wp.pl 